\title{
Functional morphology in male euglossine bees and their ability to spray fragrances (Hymenoptera, Apidae, Euglossini)
}

\author{
Benjamin BEMBÉ* \\ Zoologische Staatssammlung München (ZSM), Münchhausenstr. 21, 81247 München, Germany
}

(Received 10 January 2003; revised 12 July 2003; accepted 8 August 2003)

\begin{abstract}
Male orchid bees (Euglossini) collect fragrant substances from exogenous sources and accumulate them in modified hind tibiae. The subsequent fate of these fragrances is unknown. Here, a new hypothesis is presented that orchid bee males are capable of actively spraying off the stored fragrant substances. The fragrances are hypothesized to be transferred to the mid tibial tufts, which are then held such that when the hind wings are vibrated the jugal combs hit the tibial tufts and spray off the fragrances. To test this hypothesis, the morphology of mid tibial tufts and hind wing jugal combs was examined on male Euglossini from all known genera. The functional link between the two morphological structures could be established, including the generation of aerosol clouds. It is postulated that during the so-called "ventilating" behavior at their courtship sites the animals spray fragrances and this hypothesis is discussed with respect to previously published observations and assumptions.
\end{abstract}

Euglossini / tibial morphology / fragrance collecting / fragrance spraying / male display

\section{INTRODUCTION}

Adult males of the Euglossini are able to collect and store fragrant substances. This phenomenon has been documented and often studied since the 1960s (e.g. Vogel, 1963, 1966; Dodson et al., 1969). It plays an important role in pollination biology, because many orchids and other flowering plants have adapted to pollination by male Euglossini ("perfume flower syndrome"; Dressler, 1967, 1968; Gerlach, 1995; Heider and Bembé, 2002). Fragrance collection takes place as follows. The bee alights on a fragrant surface, e.g. an orchid flower, and examines it with the antennae. The labial glands begin to secrete self-produced lipids which are mixed with the fragrances by means of mop-like setal brushes on the front tarsi, the "tarsal brushes" (Dressler, 1982; Whitten et al., 1989). For this, the bee brushes the fragrant surface with the front tarsi. Then it takes off and assumes hover flight during which the fragrance-lipid mixture is brushed to the hind legs. Substances on the tarsal brushes are raked off by a comb-like structure on the mid metatarsus, then brushed onto the "bowl" or "slit" of the hind tibia (Evoy and Jones, 1971; Kimsey, 1984).

The hind tibiae are thickly distended due to the fragrance container, the morphology of which has been studied frequently among the five euglossine genera (Vogel, 1963, 1966; Cruz Landim et al., 1965; Sakagami, 1965; Dressler, 1982; Eltz, 1997). It contains spongiform tissue for storing the fragrance-lipid mixture. In addition, a gland is assumed to occur there ("bowl gland" of Vogel, 1966; Eltz, 1997), at least in the genus Euglossa. The subsequent fate of the fragrance-lipid mixture is as yet unknown (Kimsey, 1980; Eltz et al.,

\footnotetext{
* Corresponding author: benjaminbembe@gmx.de
} 


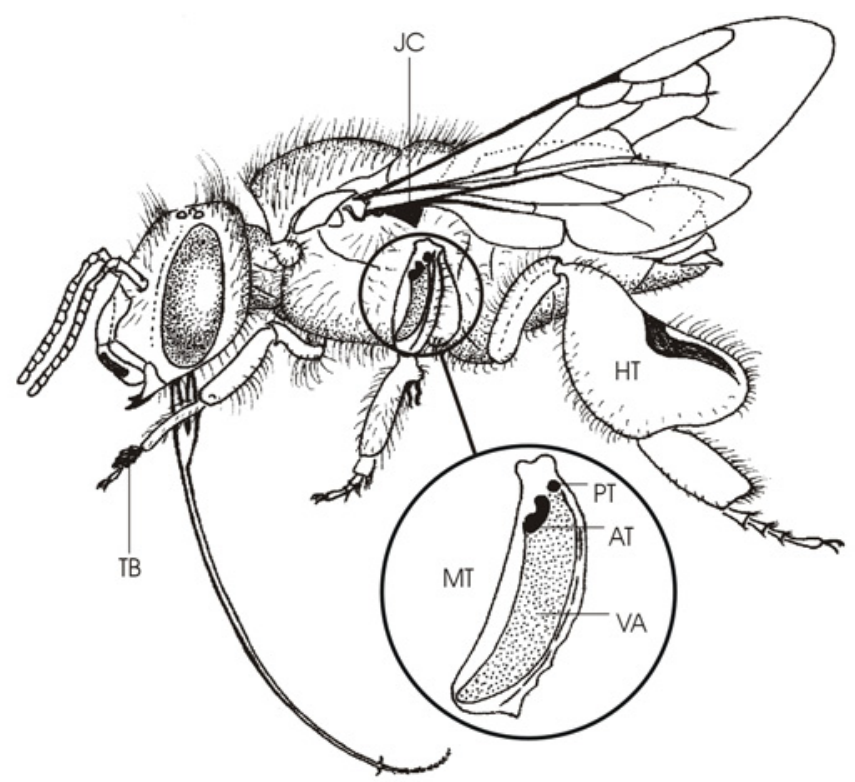

Figure 1. Overview of the investigated morphological structures of Euglossa. AT: anterior tuft, HT: distended hind tibia, JC: jugal comb, MT: middle tibia, PT: posterior tuft, TB: tarsal brush, VA: velvet area.

1999; Bembé, 2002), although several hypotheses have been formed regarding its function in euglossine biology (Dodson et al., 1969; Whitten et al., 1989).

Equally unknown is the function of the setal "tufts" on the middle tibiae of male Euglossini (Dressler, 1967, 1982; Dodson et al., 1969; Evoy and Jones, 1971). The structure of these tufts varies between the species and is thus frequently employed as a diagnostic character (Dressler, 1982; Bonilla-Gómez and NatesParra, 1992). As Kimsey (1984) and Eltz et al. (2003) have shown, they do not play an active role in the collecting of fragrances, nor in euglossine grooming behavior. The present study examines for the first time the morphology and functionality of the setal tufts, as well as that of the "jugal combs" on the hind wings. Both of these structures are known only from members of the Euglossini. Their respective morphology is here proposed to form an interacting functional system. This allows the interpretation of a variety of hitherto inexplicable behavioral observations. In addition, an hypothesis is formed on how and where the males of Euglossini release the collected fragrances.

\section{MATERIALS AND METHODS}

\subsection{Terminology}

For some morphological features of the Euglossini the terminology in the literature is variable, therefore a few definitions are necessary.

A velvety, setose area on the outer surface of the mid tibia of male Euglossini is termed "velvet area" (after Dodson et al., 1969), rather than "posterior felty patch" (Kimsey, 1982) or "large felt area" (Michener, 2000); in German "Samtfeld" (new term), not "Filzscheibe" as in Sakagami (1965). Published Portuguese and Spanish terms are "coxin" (Rebêlo and Moure, 1995) and "lunar afelpado" (Bonilla Gómes and Nates-Parra, 1992), respectively.

At the proximal end of the velvet area there are one or two, rarely three, small brushes of setae, which are here termed "tibial tufts" (after Dressler, 1978), rather than ("small") "felty patches" (Kimsey, 1982; Michener, 2000); in German "Tibialbürsten" (new term). Published Portuguese and Spanish terms are "área aveludada" (Rebêlo and Moure, 1995) and "penacho" (Bonilla Gómes and Nates-Parra, 1992), respectively. In the genus Euglossa two such tufts are usually present which, according to their respective position, are termed anterior and posterior tibial tufts (see Fig. 1). 
Members of the Euglossini, as well as of the closely related Bombini, are lacking the jugal lobe of the hind wing (Michener, 2000). In its place the Euglossini, but not the Bombini, carry a delicate, comb-like structure. In accordance with its position this structure is here termed "jugal comb" (after Kimsey, 1982), rather than "comb of bristles" (Michener, 2000); in German "Jugalkamm" (new term).

Since the names of three of the genera treated below begin with the letter E, their abbreviations are given as Ef. for Eufriesea, Eg. for Euglossa, and El. for Eulaema.

\subsection{Morphology}

SEM imaging was employed to study the jugal combs and mid tibial tufts of Ef. violacea (Blanchard, 1840), Eg. chalybeata Friese, 1925, Eg. mixta Friese, 1899, Eg. modestior Dressler, 1982, Eg. variabilis Friese, 1899, and El. meriana (Olivier, 1798). SEM preparations were affixed to electrically conducting adhesive tape and sputtered with gold for $120 \mathrm{~s}$ at $20 \mathrm{~mA}$. SEM examinations were performed on a Philips XL-20 with a high-voltage anode, at $10 \mathrm{kV}$ and settings "integrate 1", "slow scan 3".

\subsection{Histology}

The dehydrated middle tibia of a male of Eg. chalybeata were embedded in SPURR, and sectioned into layers of 1 or $2 \mu \mathrm{m}$ thickness. Serial sections were obtained for a $1.2 \mathrm{~mm}$ stretch near the proximal end of the tibia, the region carrying the anterior and posterior tibial tufts. Phase contrast microscopy was used to examine the thin sections stained with methylene blue azure II.

\subsection{Functional morphology}

The possible movement patterns of legs and wings were studied by light microscopy, including males from five euglossine genera, mostly of the species Ef. violacea (Blanchard, 1840), Eg. mixta Friese, 1899, Eg. modestior Dressler, 1982, El. meriana (Olivier, 1798), El. cingulata (Fabricius, 1804), Exaerete smaragdina (Guérin, 1845), and Aglae caerulea Lepeletier \& Serville, 1825. Animals were stored in a humid chamber for approximately 2 days. This serves to soften the leg and wing musculature and thus to restore the full mobility of these structures. Softened specimens were placed under a stereoscope where the well-known grooming and fragrance-collecting movements (after Kimsey, 1984) were artificially performed. Subsequently, other possibilities for movement were investigated by trying out which body parts could interact with each other in which ways. The behavior of fragrance-lipid mixtures was simulated by applying small droplets of water or olive oil to different setose structures of the legs.

In addition, museum collection specimens were examined for morphological structures possibly enabling the animals to spray fragrances. Specimens of approximately 120 species of Euglossini were examined at ZSM, the G. Gerlach collection (Munich), the Zoological Museum of Humboldt University (Berlin), and the collection of Euglossa species of Pe. Moure (Curitiba, Brazil).

\section{RESULTS}

Jugal combs of various Euglossini were examined by SEM. Unlike the tibial tufts and velvet area, the jugal comb is present in Euglossini adults of both sexes. However, on females it is smaller and more inconspicuous (Figs. 2a-f). On male animals the jugal comb is not only much more strongly developed, it also projects beyond the posterior edge of the wing - a fact highly significant to its hypothesized function (see below). The male jugal comb consists of a row of very strong setae with acute tips and a slightly obliquely grooved surface structure (Fig. 3a). In Eulaema these setae are all distally bent so that they touch each other and together are forming an edge (Fig. 3b). In the other genera, the setae are almost straight and slightly diverging, thus they do not touch but resemble the teeth of a comb (Figs. 3c-d). Except in Eulaema, the jugal comb is slightly twisted such that its outer edge does not parallel the wing axis (Fig. 3d). SEM images of the velvet area and tibial tufts, with their structures relevant to interpretations of functional morphology, are shown in Figures $4 \mathrm{a}-\mathrm{d}$.

A histological examination was performed to answer the question whether in the genus Euglossa there is a gland beneath the posterior mid tibial tuft. (This appeared plausible since the middle tibia is relatively thick and the tuft is situated in a depression (Figs. 4b-c).) Thin sections of Eg. chalybeata tibiae showed no evidence of a glandular organ. The mid tibia approximately equally thickened in males and females - is only traversed by a strong muscle. The inner surface of the chitinous layer is covered throughout with a thin, unicellular epithelium. No tissue was found that would have pointed to the existence of a gland.

Limb movement simulations under the stereoscope showed that in Euglossini males the 

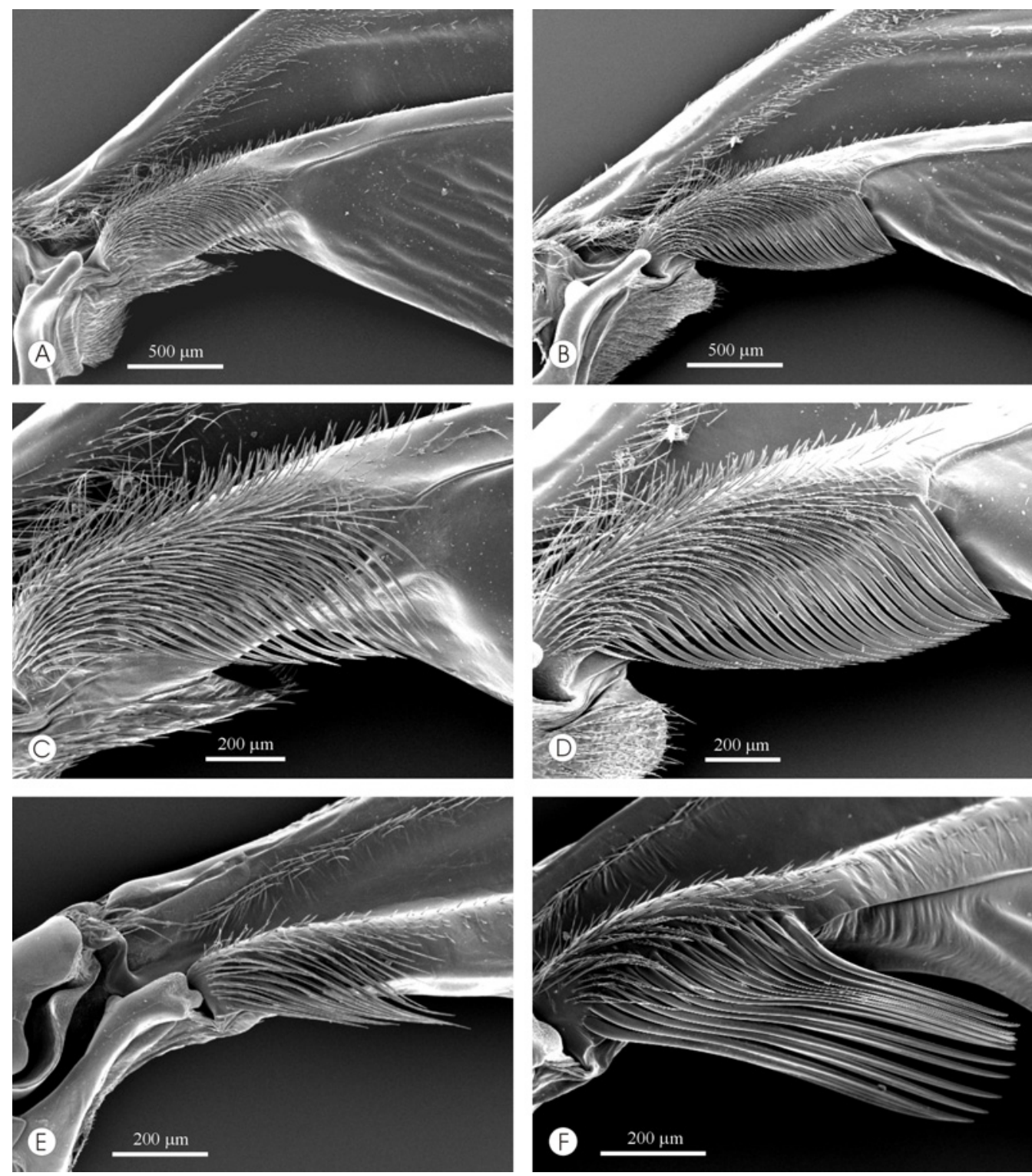

Figure 2. Jugal combs on the hind wings of Eulaema meriana (a-d) and Euglossa spp. (e-f). Combs of females (left) are essentially smaller and weaker than those of males (right). (a-b) Jugal combs on exactly the same scale; (c-d) Only the male jugal comb projects clearly beyond the posterior edge of the wing; (e) jugal comb of a female Euglossa sp. with bent setae differing in length; (f) jugal comb of a male Euglossa chalybeata with straight setae of same length.

jugal comb can be moved across the mid tibial tufts. For this the mid leg must be held alongside the body such that the tibia is positioned below the insertion of the wing. The wings must be moving perpendicular to the body axis as they do, for example, in hovering flight.
Only under these conditions is it possible to pass the jugal comb across the proximal part of the mid tibia. This means that the jugal comb can completely rake the tibial tuft(s), but not the entire velvet area. The movements which could be performed experimentally on dead 

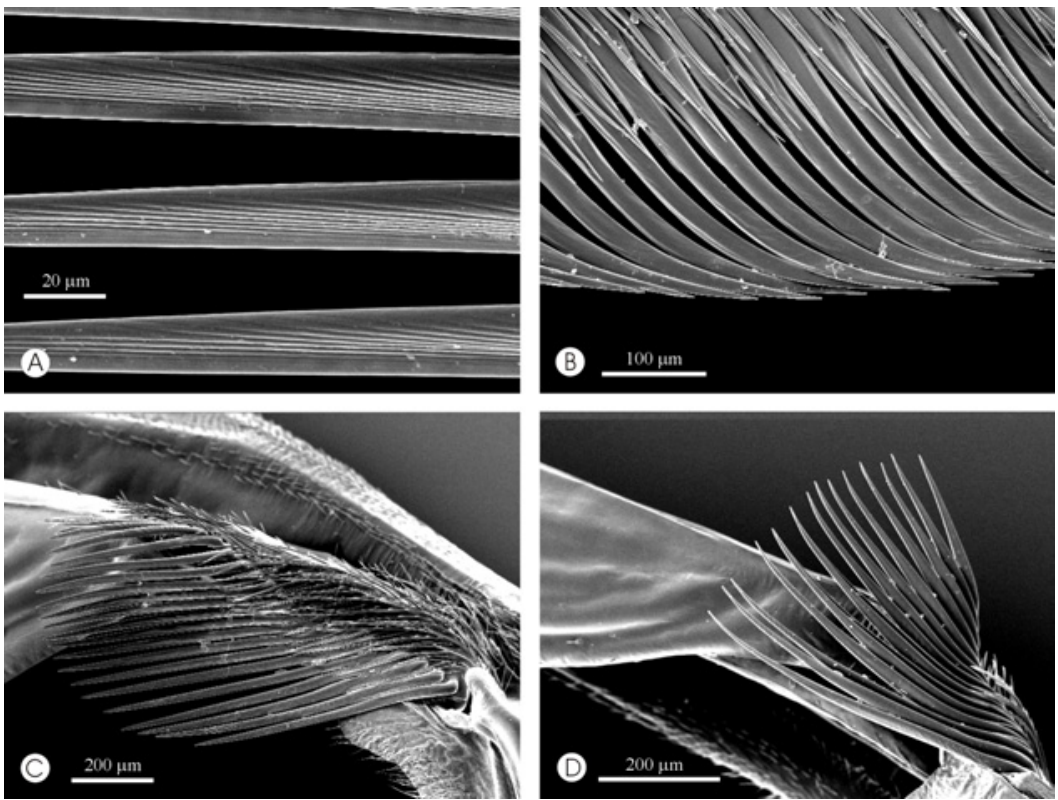

Figure 3. Variations in jugal comb structure. (a) Jugal comb setae with slightly obliquely grooved surface structure (detail from (c)); (b) setae in Eulaema meriana, distally bent, touching each other and forming an edge; (c) jugal comb of male Eufriesea violacea; (d) lateral view of male jugal comb of Euglossa mixta. It is slightly twisted such that its outer edge does not parallel the wing axis.
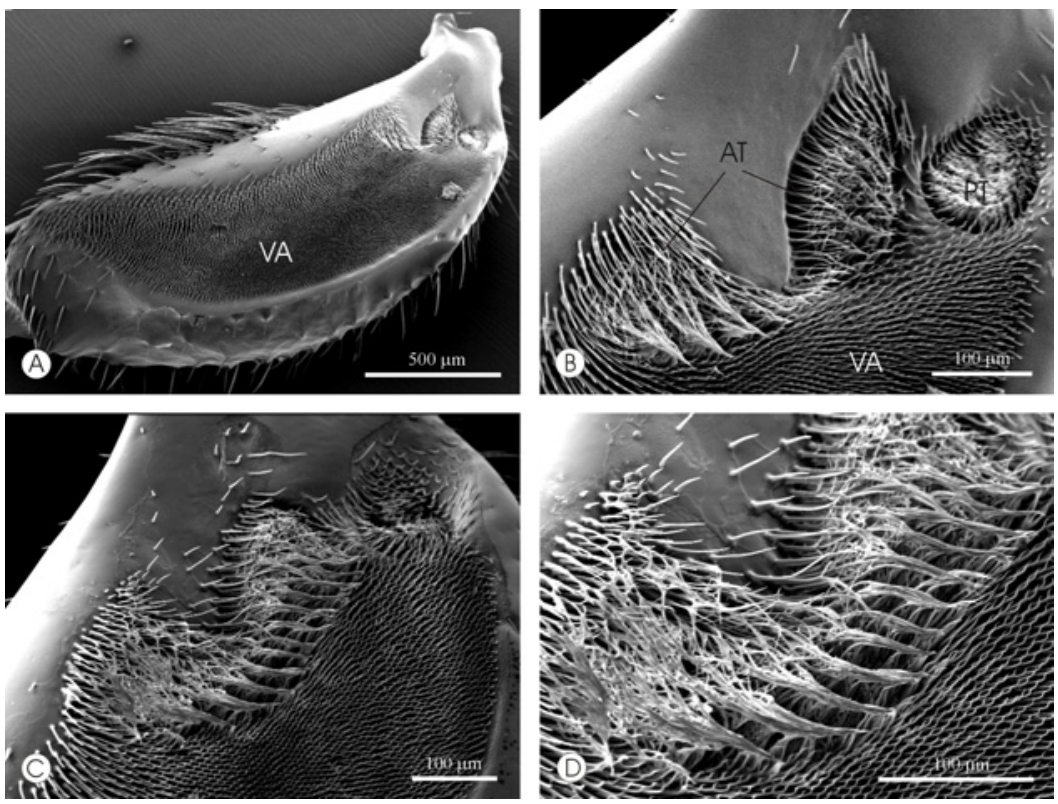

Figure 4. Mid tibial tufts of Euglossa modestior (a-b) and Eg. variabilis (c-d). (a) Whole tibia, showing proportions of velvet area and tufts; (b) the posterior tuft and a part of the anterior tuft are situated in a depression; (c) this anterior tuft shows signs of spray-ventilating: the delicate ripples resulted from the movement of the jugal comb; (d) detail of (c). AT: anterior tuft, PT: posterior tuft, VA: velvet area. 


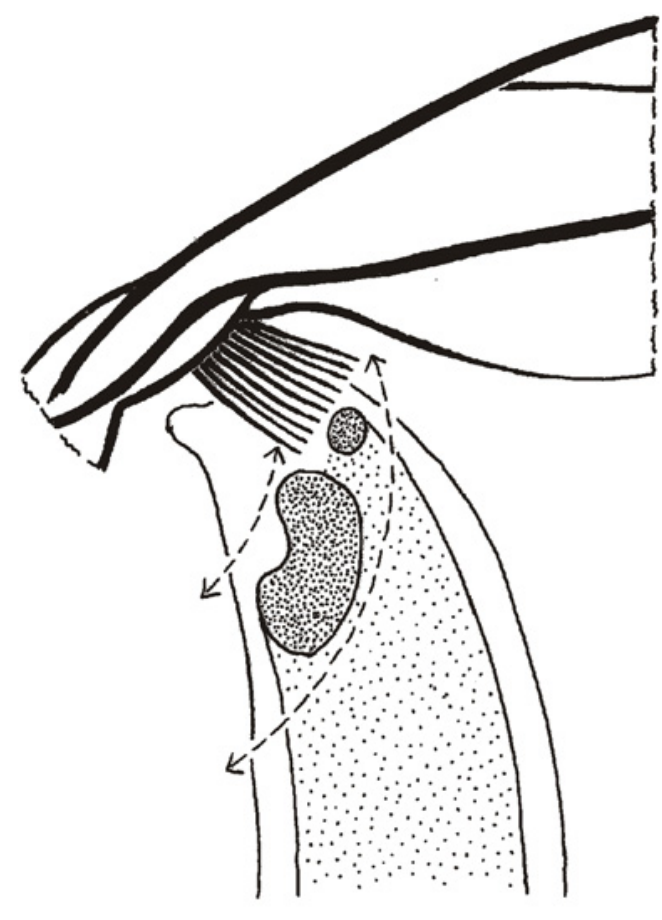

Figure 5. Scheme of the possible movement of the jugal comb assumed to occur during sprayventilating.

male specimens are shown in Figure 5. They are demonstrable for all five genera without significant differences, and for all 120 species studied.

In an experiment with El. cingulata, when a jugal comb was moved across a tibial tuft moistened with water, fine aerosol clouds being sprayed off could be observed under the stereoscope when the lighting was at favorable angles. This can be understood as analogous to the effect of a thumb rubbing across the surface of a wet toothbrush. In exceptional cases evidence that these movements are actually carried out by the living animals can even be found on museum specimens of Euglossini. The tibial tuft setae shown in Figures $4 \mathrm{c}-\mathrm{d}$ were still glued together in a ripple pattern by an oily substance even after five minutes of ultrasound treatment in an acetone solution. The ripples run at nearly $90^{\circ}$ angles to the direction of hypothetical movement of the jugal comb.

As evident from Figure 5, the direction of movement of the jugal comb is not exactly longitudinal but at a shallow angle to the axis of the tibia. Accordingly, the tibial tufts are situated in precisely the region traversable to the jugal comb. The caudally oriented edge(s) of the tuft(s) are often adapted to this movement possibility. Such a slightly convex shape has been found especially frequently in Euglossa, although outlines and structures of tibial tufts show large, species-specific variation.

As mentioned above the velvet area is usually too large to be raked completely by the jugal comb. The distal end of a maximally developed velvet area can not be reached by the jugal comb in any way. In the experiments, water or olive oil was brushed onto the velvet area. These fluids spread rapidly and evenly across the entire velvet area and the tufts. Since the latter structures are surrounded by polished, glabrous surfaces, fluids are not transmitted beyond the edge of the velvet area. A capillary continuum only exists with the tibial tuft(s). When wetted with a fluid film, the velvet area forms the equivalent of a shallow lake. When a strip of filter paper is used to draw off fluid at the proximal end of the velvet area, where the tibial tufts are located, the fluid film in the velvet area can be observed to shrink concentrically from the area's edges.

\section{DISCUSSION}

The morphological structures and their demonstrably possible interaction suggest that euglossine males possess the ability to spray off fluid substances from their mid tibial tufts by vibrating action of their hind wings. It is hypothesized that the velvet area serves as a short-term fluid storage and supply to the tibial tufts during spraying. It is postulated here that euglossine males employ a "spraying" behavior as part of their courtship displays, by which fragrance-lipid mixtures, possibly mixed with self-produced substances, are actively distributed. In this scenario, the fragrance mixtures first have to be transferred to the velvet area from which they flow to the tibial tuft(s) and can then be sprayed. The mechanism of transfer from the container in the hind tibia to the mid tibia has not yet been discovered. Vogel (1966) assumes that the collected mixture reemerges from the container passively, by capillary action, via the bowl. Since both the 
bowl and the velvet area are situated on the respective lateral sides of the legs, the two structures cannot be brought in direct contact. It is conceivable, however, that transfer occurs by a reversal of the collection process, as suggested by Peruquetti (2000). A remarkable movement pattern of the legs was also documented by Eltz et al. (2003), using video recordings of Eg. hemichlora. Eltz filmed bees hovering in front of a courtship site during territoriality displays. The recordings show how bees extend a hind leg far forward and shortly afterwards move the contralateral mid leg in the opposite, backward direction. It is possible that the two legs touch at the tibiae during these movements. It remains to be shown, however, whether substances are transferred in the process.

As far as euglossine biology is known, the spraying of fragrances would make sense only at the sites of male display behavior. Courtship and territoriality displays of male Euglossini of the genera Euglossa and Eulaema have repeatedly been documented in detail (Dodson, 1966; Vogel, 1966; Dressler, 1967; Kimsey, 1980; Eltz, 1997; Stern, 1991). In Eufriesea they have only been mentioned for Ef. schmidtiana (Friese, 1925) (Dressler, 1967; Kimsey, 1982), but without any specifics. Display behavior in Exaerete appears to largely agree with that in Euglossa. It was recently observed and filmed in Bolivia (H. Heider, pers. comm.). Several of the above observations strongly suggest that fragrances are sprayed, although none of the observers reports noticing any scent. Since display behavior patterns differ in a number of elements between Eulaema and Euglossal Exaerete, they are discussed separately below. Regular patrol flights and the territoriality displays shown when several males meet at a courtship site are not discussed here (refer to Dodson, 1975; Kimsey, 1980; Stern, 1991).

Eulaema. Display behavior has so far been documented for the species El. bombiformis (Packard, 1869), El. cingulata (Fabricius, 1804), El. meriana (Olivier, 1798), El. polychroma (Mocsáry, 1899), and El. speciosa (Mocsáry, 1897). There are no significant interspecific differences. The animals gather on trees at courtship sites at heights of $1.5-5 \mathrm{~m}$ (Vogel, 1966; Kimsey, 1980; author's observations). If a male is undisturbed it sits on the tree stem and "ventilates" for 2-3 s at a time with the wings vibrating but generating little sound. It is during these phases that the spraying of fragrances is hypothesized to take place. During ventilating, the wings are not moved backward and forward but, similarly to hovering flight, horizontally to the body axis (Stern and Dudley, 1991). Vogel (1966: 346) describes the body posture during ventilating of a specimen of $E$. meriana as follows (translated from German): "Since the animal is standing on stiff hind legs (only the tarsomeres touch the ground), the body axis is at an angle away from the substrate. Curiously, the mid legs do not appear to touch the ground, but are held adjacent to the rump in caudal direction". It is exactly this posture that in our view enables the animal to move the jugal combs across the tibial tufts. A little further down in Vogel's (op. cit.) account he writes: "Before the bee landed I twice saw those kicking movements of the hind legs otherwise accompanying the "backward packing"". This observation may mean that during the brief flights fragrances are brushed onto the velvet areas. Only further studies can show whether these kicking movements are homologous to those filmed by Eltz (1997) and Eltz et al. (2003) in Euglossa.

Euglossa/Exaerete. Fewer observations exist on the genus Euglossa (Dodson, 1966; Kimsey, 1980; Eltz, 1997). Courtship sites are located on thin trees or twigs, at heights of $0.5-1.5 \mathrm{~m}$ (Dressler, 1982). The animals do not ventilate there but sit without moving for 2-3 s before taking off for a hovering flight of 1-2 s. During the latter they hover approximately $1-2 \mathrm{~cm}$ in front of the display site. Presumably they spray during hovering by raising the mid tibial tufts against the vertically moving wings with their jugal combs. Display behavior in Exaerete $(E$. dentata or E. smaragdina) is documented here for the first time $(\mathrm{H}$. Heider film sequence and pers. comm.). The courtship site was at a height of $1.5 \mathrm{~m}$ on a sun-exposed tree of $30 \mathrm{~cm}$ diameter. Similar to the behavior in Euglossa, the male would sit for $2 \mathrm{~s}$ without moving, then take off for a hovering flight of $1 \mathrm{~s}$. The bee displayed only once for about $15 \mathrm{~min}$ and could not be observed on the following days.

Dodson et al. (1969: 1244) write: "While the bee is on the tree, he buzzes loudly every few seconds, and a fine mist can be seen to emanate from the posterior portion of the bee (it has not been possible to determine if the 
emanation is from the abdomen or the leg)". This observation, presumably made on a species of Eulaema, points to spraying in the described fashion.

The fact that Eulaema at their courtship sites generate a low hum from the wing vibration has led to a variety of speculations. Dodson (1975) investigated whether the vibrating sound could attract other Euglossini but could not confirm this. Kimsey (1980) proposed the alternative interpretation that the wings of El. meriana, which during the frequent pauses between ventilating phases are folded over the abdomen, are used to send out optical signals. For a third interpretation, Stern and Dudley (1991) conclude that ventilating in El. meriana serves the purpose of thermoregulation by fanning a stream of air across the abdomen. They postulate that this causes a cooling effect distinctly overcompensating the heating due to the wing muscle action. In addition, they equate euglossine bee ventilating with the cooling fanning performed by honey bees in their nests, but we consider this to be unconvincing.. The thermoregulation hypothesis also leaves open the question why El. meriana position themselves for "cooling" exposed to direct sunlight, whereas Eg. imperialis ventilate in the shade (Kimsey, 1980).

Compared to the above assumptions, the interpretation presented here is considered more plausible based on the available information. However, only direct observations on living bees will show whether the spraying of fragrances actually takes place as postulated and, if so, what the significance and purpose of such behavior may be.

\section{ACKNOWLEDGMENTS}

For their valuable help with many euglossine issues I thank Günter Gerlach (Botanischer Garten München) and Klaus Schönitzer (ZSM). I am also grateful to Helmut Heider (München / Bolivia) for the material placed at my disposal and for numerous observations and film sequences from the rainforest. I also thank Thomas Eltz for some discussions on the manuscript. Eva Lodde (ZSM) is thanked for making the histological thin sections, Frank Reckel (Zoologisches Institut der Universität München) for permission to use the institute's SEM, and Martin Spies (ZSM) for translating the German manuscript into English.
Résumé - Morphologie fonctionnelle chez les mâles d'abeilles euglossines (Hymenoptera, Apidae, Euglossini) et leur capacité à diffuser des matières odorantes. Les abeilles euglossines mâles récoltent des substances odorantes (par ex. des odeurs de fleurs) sur des sources exogènes et les emmagasinent dans leurs tibias postérieurs qui ont subi une modification dans ce sens (Fig. 1). Ce phénomène joue un rôle important dans la biologie de la pollinisation, en particulier des orchidées. Ce que deviennent ensuite ces substances reste inconnu à ce jour. Dans ce travail nous avançons une nouvelle hypothèse selon laquelle les mâles des euglossines possèdent la capacité de diffuser activement les matières odorantes emmagasinées. Selon cette hypothèse les substances sont transférées sur les brosses des tibias des pattes médianes. Elles sont ensuite maintenues de façon à ce que, lors de la vibration des ailes postérieures, les « peignes jugaux », situés sur les ailes postérieures, frottent les brosses des tibias et diffusent les substances. Afin de tester cette hypothèse nous avons étudié la morphologie des brosses des tibias médians et des peignes des ailes postérieures chez les mâles de tous les genres d'Euglossini connus (Figs. 2-4). Par des essais sur du matériel récolté rendu souple par humectation, le lien fonctionnel entre les deux structures morphologiques a pu être établi (Fig. 5). On a pu ainsi produire des nuages aérosols. On suppose que les insectes diffusent les substances odorantes sur les sites de parade nuptiale par ce qu'on appelle le «comportement de ventilation ». L'hypothèse est discutée par rapport aux observations et aux théories précédemment publiées.

Euglossini / morphologie / tibia / substance odorante / récolte / diffusion / parade nuptiale

Zusammenfassung - Untersuchungen zur Funktionsmorphologie männlicher Euglossini und ihrer Fähigkeit, Duftstoffe zu versprühen (Hymenoptera, Apidae, Euglossini). Männliche Prachtbienen (Euglossini) sammeln Duftstoffe (z. B. Blütendüfte) an exogenen Quellen und speichern sie in ihren zu diesem Zweck modifizierten Hintertibien (Abb. 1). Was weiter mit den gesammelten Substanzen geschieht, ist bisher nicht bekannt. In der vorliegenden Arbeit wird eine neue Hypothese aufgestellt, nach welcher Prachtbienenmännchen die Fähigkeit besitzen, die gespeicherten Duftstoffe aktiv zu versprühen. Nach dieser Hypothese werden die Substanzen auf die Tibialbürsten der Mittelbeine gebracht. Diese werden dann so gehalten, dass bei vibrierenden Hinterflügeln die Jugalkämme über die Tibialbürsten streifen und die Substanzen versprühen. Um diese Hypothese zu testen, wurden an männlichen Euglossini aller bekannter Gattungen die Tibialbürsten der Mitteltibien und die Jugalkämme der Hinterflügel morphologisch untersucht (Abb. 2-4). Durch Versuche an angefeuchtetem und dadurch beweglich gemachtem Sammlungsmaterial wurden 
beide Strukturen in einen funktionsmorphologischen Zusammenhang gebracht (Abb. 5). Auf diese Weise konnten im Experiment Aerosolwolken erzeugt werden. Es wird postuliert, dass die Tiere beim sog. ,Ventilieren“ an ihren Balzplätzen Duftstoffe versprühen und die aufgestellte Hypothese mit den bisherigen Beobachtungen und Theorien aus der Literatur diskutiert.

\section{Euglossini / Tibia Morphologie / Sammeln von Duftstoffen / Versprühen von Duftstoffen / Balzverhalten}

\section{REFERENCES}

Bembé B. (2002) Prachtbienenfunde aus Panguana, Huánuco, Peru (Hymenoptera, Apidae, Euglossini), Spixiana 25, 245-249.

Bonilla-Gómez M.A., Nates-Parra G. (1992) Abejas euglosinas de Colombia (Hymenoptera: Apidae) I. Claves ilustradas, Caldasia 17, 149-172.

Cruz Landim da C., Stort A.C., Costa Cruz da M.A., Kitajima E.W. (1965) Órgão tibial dos machos de Euglossini. Estudo ao microscópio óptico e eletrônico, Rev. Bras. Biol. 25, 323-341.

Dodson C.H. (1966) Ethology of some bees of the tribe Euglossini (Hymenoptera: Apidae), J. Kans. Entomol. Soc. 39, 607-629.

Dodson C.H. (1975) Coevolution of orchids and bees, in: Gilbert L.E., Raven P.H. (Eds.), Coevolution of animals and plants, University of Texas Press, Austin, pp. 91-99.

Dodson C.H., Dressler R.L., Hills H.G., Adams R.M., Williams N.H. (1969) Biologically active compounds in orchid fragrances, Science 164, 1243-1249.

Dressler R.L. (1967) Why do euglossine bees visit orchid flowers? Atas Simp. Biota Amazônica 5, 171-180.

Dressler R.L. (1968) Observations on orchids and euglossine bees in Panama and Costa Rica, Rev. Biol. Trop. 15, 143-183.

Dressler R.L. (1978) An infrageneric classification of Euglossa, with notes on some features of special taxonomic importance (Hymenoptera; Apidae), Rev. Biol. Trop. 26, 187-198.

Dressler R.L. (1982) Biology of the orchid bees (Euglossini), Annu. Rev. Ecol. Syst. 13, 373-394.

Eltz T. (1997) Zur Duftstoffbiologie neotropischer Prachtbienen (Apidae: Euglossini), Diploma thesis, University Würzburg, Germany.

Eltz T., Roubik D.W., Whitten W.M. (2003) Fragrances, male display and mating behaviour of Euglossa hemichlora - a flight cage experiment, Physiol. Entomol. 28, 251-260.
Eltz T., Whitten W.M., Roubik D.W., Linsenmair K.E. (1999) Fragrance collection, storage, and accumulation by individual male orchid bees (Apidae: Euglossini), J. Chem. Ecol. 25, 157176.

Evoy W.H., Jones B.P. (1971) Motor patterns of male euglossine bees evoked by floral fragrances, Anim. Behav. 19, 583-588.

Gerlach G. (1995) Duftanalysen - ein Schlüssel zum Verständnis der Bestäubungsbiologie neotropischer Parfümblumen, Rundgespr. Kommiss. Ökologie 10, 231-240.

Heider H., Bembé B. (2002) Gefährdete Urwaldjuwelen, Vogelschutz - Mag. für Arten- und Biotopschutz 3, 28-30.

Kimsey L.S. (1980) The behaviour of male orchid bees (Apidae, Hymenoptera, Insecta) and the question of leks, Anim. Behav. 28, 996-1004.

Kimsey L.S. (1982) Systematics of bees of the genus Eufriesea, Univ. Calif. Publ. Entomol. 95, 1-125.

Kimsey L.S. (1984) The behavioural and structural aspects of grooming and related activities in euglossine bees (Hymenoptera: Apidae), J. Zool. (Lond.) 204, 541-550.

Michener C.D. (2000) The bees of the world, Johns Hopkins University Press, Baltimore.

Peruquetti R.C. (2000) Function of fragrances collected by Euglossini males (Hymenoptera: Apidae), Entomol. Gen. 25, 33-37.

Rebêlo J.M.M., Moure J.S. (1995) As espécies de Euglossa Latreille do nordeste de São Paulo (Apidae, Euglossinae), Rev. Bras. Zool. 12, 445466.

Sakagami S.F. (1965) Über den Bau der männlichen Hinterschiene von Eulaema nigrita Lepeletier (Hymenoptera, Apidae), Zool. Anz. 175, 347354.

Stern D.L. (1991) Male territoriality and alternative male behaviors in the euglossine bee, Eulaema meriana (Hymenoptera: Apidae), J. Kans. Entomol. Soc. 64, 421-437.

Stern D.L., Dudley R. (1991) Wing buzzing by male orchid bees, Eulaema meriana (Hymenoptera: Apidae), J. Kans. Entomol. Soc. 64, 88-94.

Vogel S. (1963) Das sexuelle Anlockungsprinzip der Catasetinen- und Stanhopeen-Blüten und die wahre Funktion ihres sog. Futtergewebes, Österr. Bot. Z. 110, 308-337.

Vogel S. (1966) Parfümsammelnde Bienen als Bestäuber von Orchidaceen und Gloxinia, Österr. Bot. Z. 113, 302-361.

Whitten W.M., Young A.M., Williams N.H. (1989) Function of glandular secretions in fragrance collection by male euglossine bees (Apidae: Euglossini), J. Chem. Ecol. 15, 1285-1295. 